\title{
Perbandingan Agility Pada Pemain Sepak Bola Paska Rehabilitasi Rekonstruksi Anterior Cruciate Ligament Dengan Pemain Sepak Bola Sehat
}

\author{
Halim Mardiyanto ${ }^{1}$, Suryo Saputra Perdana ${ }^{2}$, Ihsan Norazmi ${ }^{3^{*}}$ \\ ${ }^{1}$ Rumah Sakit Umum Daerah KRMT Wongsonegoro, Semarang. \\ Jl. Fatmawati No. 1, Mangunharjo, Semarang 50272, Jawa Tengah, Indonesia \\ ${ }^{2,3}$ Program Studi Fisioterapi, Fakultas Ilmu Kesehatan, Universitas Muhammadiyah Surakarta. \\ J1. Ahmad Yani, Kartasura, Surakarta 57169, Jawa Tengah, Indonesia \\ Email: 'halimmardianto43@gmail.com; ${ }^{2}$ suryo.saputra@ums.ac.id; ${ }^{3}$ Ihsannorazmi@gmail.com
}

Tanggal Submisi: 16 Desember 2020; Tanggal Penerimaan: 29 Desember 2020

\begin{abstract}
ABSTRAK
Ligamentum cruciatum anterior (ACL) adalah salah satu yang paling banyak ligamen yang biasanya mengalami cedera pada lutut. Tingkat cedera tahunan untuk atlet yang kompetitif adalah setinggi $3,67 \%$, Jumlah tertinggi cedera ACL adalah berkelanjutan di antara atlet yang terlibat dalam kecepatan tinggi atau olahraga multi arah seperti bola basket, dan sepak bola. Dalam olahraga yang diberikan, atlet wanita mempunyai tingkat insiden cedera ACL lebih tinggi daripada laki-laki. Sekitar 70\% cedera ACL terjadi sebagai akibat dari mekanisme noncontact, seperti pendaratan dari lompatan. Agility yang biasanya disebut kelincahan adalah kapasitas fisik yang penting untuk kinerja olahraga. kelincahan secara keseluruhan didefinisikan sebagai kemampuan untuk bergerak dan mengendalikan tubuh secepat mungkin selama akselerasi, deselerasi, dan perubahan arah. Tujuan dari penelitian ini adalah untuk mengetahui perbedaan kemampuan agility antara pemain sepak bola yang pernah rekonstruksi anterior cruciate ligament dengan pemain sepak bola sehat atau yang tidak pernah melakukan rekonstruksi anterior cruciate ligament. Metode Penelitian yang dilakukan adalah penelitian observasional yang berbasis populasi, dimana desain yang digunakan adalah crosssectional study, bertujuan untuk mencari perbedaan agility antara pemain sepak bola yang pernah melakukan rekonstruksi anterior cruciate ligament (ACL) dengan pemain sepak bola sehat atau tidak pernah rekonstruksi anterior cruciate ligament.
\end{abstract}

Kata Kunci: ACL, Kelincahan, Illinois agility test

\begin{abstract}
The anterior cruciate ligament (ACL) is one of the most numerous ligaments that usually have a knee injury. The annual injury rate for competitive athletes is as high as $3.67 \%$, the highest number of ACL injuries is sustained among athletes involved in high-speed or multi-directional sports such as basketball and soccer. In the sport given, female athletes have a higher incidence of ACL injuries than men. About $70 \%$ of ACL injuries occur as a result of non-contact mechanisms, such as landings from jumps. Agility, which is usually called agility, is a physical capacity that is important for sports performance. overall agility is defined as the ability to move and control the body as fast as possible during acceleration, deceleration, and change in direction. The purpose of this study was to determine the differences in the ability of agility between soccer players who have reconstructed the anterior cruciate ligament with healthy soccer players or who have never reconstructed the anterior cruciate ligament. The research method used is population-based observational research, where the design used is a cross- sectional study, aimed at finding differences in agility between soccer players who have performed anterior cruciate ligament reconstruction (ACL) with healthy soccer players or never anterior reconstruction cruciate ligament.
\end{abstract}

Keywords: ACL, Agility, Illinois agility test 


\section{PENDAHULUAN}

Anterior Cruciate Ligament merupakan bagian dari empat ligamen utama yang menstabilisasi sendi lutut. Anterior Cruciate Ligament (ACL) dan Posterior Cruciate Ligament (PCL) terentang dari tulang disekitar fosa interkondiler femur sampai ketibia masingmasing didepan dan dibelakang interkondiler. Penamaan anterior dan posterior berdasarkan perlekatannya pada tibia. Kedua ligamen ini saling menyilang seperti huruf X. ACL melonggar ketika knee fleksi dan tegang ketika ekstensi penuh. Mencegah tulang tibia dari pergeseran yang berlebihan dan menstabilisasi knee dalam melakukan berbagai aktivitas. Posterior Cruciate Ligament tegang ketika knee joint fleksi dan berguna untuk membatasi pergerakan femur ke anterior dan tibia ke posterior terutama ketika knee fleksi (Santoso et al., 2018).

Agility yang biasanya disebut kelincahan adalah kapasitas fisik yang penting untuk kinerja olahraga. kelincahan secara keseluruhan didefinisikan sebagai kemampuan untuk bergerak dan mengendalikan tubuh secepat mungkin selama akselerasi, deselerasi, dan perubahan arah. Kinerja olahraga yang sukses tergantung tidak hanya pada waktu gerakan tetapi juga pada kemampuan atlet untuk dengan cepat dan efektif mendefinisikan arah di mana ia harus berlari (França, Loureiro, \& Freitas, 2016). Illinois agility test digunakan untuk menentukan kemampuan dalam menambah dan mengurangi kecepatan, mengubah arah serta lari pada sudut yang berbeda (Nawi \& Homoud, 2015). Illinois agility test adalah suatu tes yang digunakan untuk mengukur kelincahan atlet. Menurut Horasani et al. (2010) illinois agility test adalah salah satu tes terbaik untuk mengukur kelincahan atlet sepak bola. Berdasarkan Younes et al. (2013) illinois agility test memiliki reability dan validity $95 \%$ atau 0,95 yang artinya tes ini memiliki nilai sangat baik untuk pengukuran kelincahan atlet.

\section{METODE}

Penelitian yang dilakukan adalah penelitian dengan metode observasional yang berbasis populasi, dimana desain yang digunakan adalah cross-sectional study, bertujuan untuk mencari perbedaan agility antara pemain sepak bola yang pernah melakukan rekonstruksi anterior cruciate ligament (ACL) dengan pemain sepak bola sehat atau tidak pernah rekonstruksi anterior cruciate ligament. Pengukuran penelitian dilakukan satu kali pada satu waktu, variable diukur secara bersamaan dan tidak ada follow up.

\section{HASIL DAN PEMBAHASAN}

\section{HASIL}

\section{Hasil Pengukuran Agility}

Tabel 1. Hasil pengukuran agility post ACLR

\begin{tabular}{ccccc}
\hline Valid & $\begin{array}{c}\text { Frequen } \\
\text { cy }\end{array}$ & $\begin{array}{c}\text { Percen } \\
\mathbf{t}\end{array}$ & $\begin{array}{c}\text { Valid } \\
\text { Percen } \\
\mathbf{t}\end{array}$ & $\begin{array}{c}\text { Cumul } \\
\text { ative } \\
\text { Percent }\end{array}$ \\
\hline $\begin{array}{c}\text { Excele } \\
\text { nt }\end{array}$ & 3 & 30,0 & 30,0 & 30,0 \\
\hline $\begin{array}{c}\text { Very } \\
\text { Good }\end{array}$ & 7 & 70,0 & 70,0 & 70,0 \\
\hline Total & $\mathbf{1 0}$ & $\mathbf{1 0 0 , 0}$ & $\mathbf{1 0 0 , 0}$ & \\
\hline
\end{tabular}

Dari tabel hasil pengukuran agility menggunakan Illinois Agility Test maka didapatkan hasil 3 pemain dengan persentase $30 \%$ memiliki kategori excellent dan 7 (70\%) pemain memiliki kategori very good.

Tabel 2. Hasil pengukuran agility pemain sehat

\begin{tabular}{ccccc}
\hline Valid & $\begin{array}{c}\text { Freque } \\
\text { ncy }\end{array}$ & Percent & $\begin{array}{c}\text { Valid } \\
\text { Percent }\end{array}$ & $\begin{array}{c}\text { Cumula } \\
\text { tive } \\
\text { Percent }\end{array}$ \\
\hline $\begin{array}{c}\text { Excellent } \\
<\mathbf{1 5 . 2 0}\end{array}$ & 9 & 90,0 & 90,0 & 90,0 \\
\hline $\begin{array}{c}\text { Very } \\
\text { Good }\end{array}$ & 1 & 10,0 & 10,0 & 10,0 \\
$\mathbf{1 5 . 2 1}-$ & & & & \\
\hline $\mathbf{1 6 . 1 0}$ & & & & \\
\hline Total & $\mathbf{1 0}$ & $\mathbf{1 0 0 , 0}$ & $\mathbf{1 0 0 , 0}$ & \\
\hline
\end{tabular}

Dari tabel di atas maka didapatkan hasil bahwa 9 pemain memiliki kategori excellent $(90 \%)$ dan 1 pemain kategori very good (10\%)

\section{PEMBAHASAN}

ACL (Anterior Cruciate Ligamen) merupakan salah satu ligamen yang berfungsi untuk menjaga stabilitas sendi lutut terhadap perubahan arah gerak dan berbagaai posisi. Agility merupakan salah satu komponen yg ada pada performa atlet untuk mencapai performa yang baik. Agility yang biasanya disebut kelincahan adalah kapasitas fisik yang penting untuk kinerja olahraga. kelincahan secara keseluruhan didefinisikan sebagai kemampuan untuk bergerak dan mengendalikan tubuh secepat mungkin selama akselerasi, deselerasi, dan perubahan arah. Hasil dari tes menunjukkan nilai $\mathrm{p}>0.05$, berarti Ha ditolak dan Ho diterima yang artinya bahwa agility yang 
dimiliki oleh sampel pemain sepak bola yang telah menjalani rehabilitasi paska rekonstruksi ACL dengan agility yang dimiliki oleh pemain sepak bola sehat tidak terdapat perbedaan.

Menurut (Mihelic \&Radovan, 2011) menunjukkan bahwa pemain sepak bola usia 1720 tahun post ACLR memiliki kestabilan lutut yang baik daripada yang non ACLR paska rehabilitasi. Hal ini dibuktikan dari hasil penelitian menunjukkan $83 \%$ post ACLR memiliki kestabilan lutut hingga memiliki kedekatan dengan IKDC dan $84 \%$ pemain non ACLR memiliki kestabilan lutut yang kurang. Pada pemain post rekonstruksi ACL, setelah operasi mendapatkan treatment secara langsung oleh fisioterapi memiliki peningkatan yang signifikan dibanding yang tidak langsung ditangani fisioterapis. Dalam segala aspek kecepatan maupun kelincahan dan durasi waktu yang lama (8 bulan) akan memberikan dampak yg sangat baik pada pemain post ACLR (Krolikowska \& Aleksandra, 2018).

\section{KESIMPULAN}

Berdasarkan hasil Uji Penelitian dan pembahasan maka dapat disimpulkan bahwa agility yang dimiliki oleh pemain yang telah menjalani rehabilitasi paska rekonstruksi ACL
(Anterior Cruciate Ligamen) tidak berbeda dengan agility yang dimiliki oleh pemain yang sehat pada beberapa klub sepak bola amatir di Semarang.

\section{DAFTAR PUSTAKA}

Khayambashi, K., Ghoddosi, N., Straub, R. K., \& Powers, C. M. (2015). The American Journal of Sports Medicine $P<P$ Hip Muscle Strength Predicts Injury in Male and Female Athletes.

Nawi, M., \& Homoud, A. (2015). Relationships between illinois agility test and reaction time in male athletes. The Swedish Journal of Scientific Research, 2(3), 28-33.

Nicholls, A., \& Sintonen, K. (2018). Developing a Football Training Product (eBook).

Paulsen, F., \& Waschke, J. (2014). Atlas of Human Anatomy General Anatomy andMusculoskeletal System.

Santoso, I., Dwi, I., Sari, K., Noviana, M., \& Pahlawi, R. (2018). Penatalaksanaan Fisioterapi Pada Post Op Rekonstruksi Anterior Cruciate Ligament Sinistra Grade III Akibat Ruptur Di RSPAD Gatot Soebroto. 1, 66-80. 